\title{
Effect of Exogenous Application of 24-Epibrassinosteroids and Hydrogen Peroxide on Some Biochemical Characteristics of Cuminum cyminum L. grown under Drought Stress
}

\author{
Hossein Abbaspour ${ }^{1^{*}}$, Nasim Roudbari ${ }^{2}$, Khosrow Manouchehri Kalantari $^{3}$, Ahmad Aien ${ }^{4}$ \\ ${ }^{1}$ Department of Biology, North Tehran Branch, Islamic Azad University, Tehran, Iran \\ ${ }^{2} \mathrm{PhD}$ Student of Biology, Department of Biology, Islamic Azad Uiversity, Damghan, Iran \\ ${ }^{3}$ Department of Biology, Shahid Bahonar University of Kerman, Kerman, Iran \\ ${ }^{4}$ Seed and Plant Improvement Department, South kerman Agricultural and Natural Resources Research and Education center, \\ Agriculture research, Education and Extension Organization (AREEO), Jiroft, Iran
}

\begin{abstract}
To evaluate the responses of cumin plant to different levels of drought stress with exogenous application of either 24-epibrassinolide (24-EBL) or hydrogen peroxide $\left(\mathrm{H}_{2} \mathrm{O}_{2}\right)$ and a mixture of them, a factorial experiment was conducted, in a complete randomized design with three replicas, at the experimental greenhouse. Treatments included three levels of drought stress $(100 \%, 75 \%$, and $50 \%$ of FC) in which at fifth week after germination (beginning of reproductive growth) application of $\mathrm{H}_{2} \mathrm{O}_{2}(0,0.5$ and $1 \mathrm{mM})$ and 24-epibrassinosteroid $(0,0.5$ and $1 \mathrm{mM}$ ) at two stages, first 3 days before applying the then, 15 days after. The results showed that with increasing stress intensity, the amounts of proline, malondialdehyde and superoxide dismutase (SOD) enzyme increased, but decreased the total protein and catalase enzyme in the root. The results of interaction between drought stress and exogenous application of 24-EBL showed the highest total protein content $(11.30 \mathrm{mg} / \mathrm{l})$ at $1 \mathrm{mM} 24-\mathrm{EBL}$ under moderate stress of $75 \%$ of FC. Also, the highest of proline content of the root and shoot were obtained (10.15 and

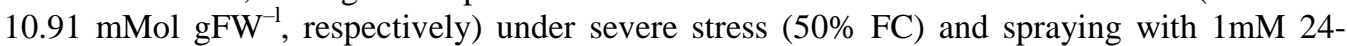
EBL, respectively. However, a decrease in MDA content, with the application of 24-EBL e and $\mathrm{H}_{2} \mathrm{O}_{2}$, was recorded. In general, it can report that drought stress reduced the efficiency of photosynthesis and plant production. Moreover, application of 24-EBL and $\mathrm{H}_{2} \mathrm{O}_{2}$ was able to improve the photosynthetic system and resistance of the cumin plant to stress.
\end{abstract}

Keywords: Antioxidant enzymes, Cumin (Cuminum cyminum L.), Drought stress, Malondialdehyde, 24-epibrassinosteroid.

\section{INTRODUCTION}

Medicinal plants are very valuable resources in the wide areas of natural resources in Iran, in case of which scientific knowledge, domestication, cultivation, development and optimal utilization can play an important role in health, employment and export. Cumin (Cuminum cyminum L.) is an annual plant belonging to the family Apiaceous, which is one of the most important and widely used medicinal plants. The family is mainly cultivated for various industries such as pharmaceuticals, food, cosmetics and sanitation (Omidbeigi, 2007). One of the most important research fields for medicinal plants is the study of environmental conditions affecting the qualitative and quantitative performance of these plants. Drought stress is one of the most important limiting factors for plant growth and in sequence affects many metabolic path-ways such as photosynthesis, respiration, absorption and transfer of water, mineral elements, enzyme activities, and the transfer and accumulation of organic matter (Suzuki et $a l .$, 2012). Therefore, the degradation effect of drought stress, especially in areas with low water reserves or poor rainfall distribution, is more than any other abiotic stress (Einizade et al., 2016). In drought tolerant- plants to environmental abiotic stresses, some morphological and metabolic changes occurred in response to stress that result in plant adaptation to the limiting environmental conditions (Xocon-ostle-Cazares et al., 2012). The cultivation of medicinal plants under water deficit conditions needs to be considered for their ability to produce in a wide area, and to assess their resistance to adverse environmental conditions, including drought. In studying the effect of different levels of drought stress (30, 60 and $100 \%$ of field capacity) on the activity of some antioxidant enzymes, photosynthetic pigments, proline and yield of Borago officinalis, Gholi Nejad et al., (2014) concluded that with increasing drought stress, the yield and photosynthetic pigments decreased and proline content and antioxidant enzymes increased. Since drought stress is one of the biggest challenges in the production of crops in the arid and semi-arid areas, identifying the different reactions of medicinal plants to water deficit is important (Moghaddam et al., 2014). Under abiotic stress conditions, drought stress has led to a $45 \%$ reduction in crop yields in different parts of the world (Kafi et al., 2009) and causes similar cell damage along with salinity stress, temperature stress and oxidative stress (Lisar et al., 2012; Daghino et al., 2016). Among the physiological and metabolic changes that may occur in response to the drought and salinity stresses, reactive oxygen species (ROS), such as superoxide radicals $\left(\mathrm{O}^{2}\right)$ and a single oxygen $\left(\mathrm{O}^{1-}\right)$, hydroxide radicals $\left(\mathrm{OH}^{-}\right)$ and along with them the formation of $\mathrm{H}_{2} \mathrm{O}_{2}$ increase under stress conditions in cell organelles in plants (Sharma et al., 2012).

Plants have an antioxidant system that controls the excess production of (reactive oxygen species) ROS under stress conditions and thus protects them against 
the harmful effects of ROS, and, on the other hand, provides a managed level of ROS for growth and signal transmission pathways (Ishibashi et al., 2012). This antioxidant defense system includes antioxidants such as $\beta$-carotene, ascorbic acid, $\alpha$-tocopherol and reduced glutathione (GSH), as well as antioxidant enzymes including catalase, ascorbate peroxidase, glutathione reductase and guaiacol peroxidase (Benhmimou et al., 2018). Under stress conditions, ROS caused by the biotic and abiotic stresses stimulate the degrading processes of membrane fatty acids, and thus, malondialdehyde increases under drought stress conditions, which indicates the membrane lipid peroxidation. Investigating the concentration of malondialdehyde in plant tissues can indicate the degree of destruction of the cell membrane because it is released by the degradation and peroxidation of the cell membrane (Bhattacharjee, 2012).

ROS-scavenging enzymes neutralize the toxic effects of ROS, which may be the result of continuous and simultaneous action of a number of antioxidant enzymes including catalase (CAT), peroxidase (POD), superoxide dismutase (SOD) and ascorbate peroxidase (APX). Plant cells are equipped with a free radical scavenging system to protect against oxidative damage (Hussein and Alva, 2014).

Hydrogen peroxide $\left(\mathrm{H}_{2} \mathrm{O}_{2}\right)$ works as a regulator in various physiological processes, including photosynthesis (Noctor et al., 2017), aging (Gao et al., 2010), stomatal movement, cell growth and develo-pment (Suzuki et al., 2012). When the amount of hydrogen peroxide in the cell is maintained at a natural level by a series of antioxidant enzymes, it works as a secondary messenger along with other cellular signals to protect the plants from stress and stimulate stress tolerance (Qiao et al., 2014; Choudhury et al., 2017; Caverzan et al., 2016). Shan et al., (2018) stated that the treatment of plants with exogenous $\mathrm{H}_{2} \mathrm{O}_{2}$ prevents from increasing oxi-dative stress and tolerance of plants to salinity stress by increasing the production of the antioxidant enzyme and non-enzymatic compounds that can modulate ROS and lipid peroxidation.

Brassinosteroids are also one of the cellular signaling compounds that can increase plant resistance to the environmental stresses (Siddiqui et al., 2018). For example, the treatment of various plants such as grapes (Seif et al., 2014) under drought stress conditions, rice (Lisar et al., 2012) and cucumber (Fariduddin et al., 2014) under low temperature stress conditions by brassinosteroids showed better growth than the control plants.

According to the previous research, most areas cultivated with cumin in Iran are related to the arid and semiarid areas. Due to water deficit in the agricultural sector in these areas, research into the proper use of water in this sector is necessary (Kafi et al., 2006; Bahraminejad, 2011).

Therefore, the purpose of this study was to study the protective role of hydrogen peroxide and brassinosteroids and there interaction with oxidative stress caused by drought stress.

\section{MATERIALS AND METHODS}

This study was conducted in the fall of 2016 in a research greenhouse of Agricultural Research, Education and Extension Organization (AREEO) in the south of Kerman Province. A factorial experiment, in a completely randomized design with three replications, was carried out. The investigated factors included: three different levels of irrigation based on field capacity (FC) (50, 75 and 100\% FC) (Benhmimou et al., 2018). With the beginning of flowering period, drought stress was applied; in the fifth week after cultivation, based on FC, mild stress: $75 \%$ of FC and severe stress: $50 \%$ of FC, based on the amount of water needed for each pot was conducted. Three days before applying drought stress, the 24-epibrassinosteroid (Br: Sigma Aldrich) hormone at $(0,0.5$ and $1 \mathrm{mM})$ and hydrogen peroxide $\left(\mathrm{H}_{2} \mathrm{O}_{2}: 30 \%\right.$ Merck- $0,0.5$ and 1 $\mathrm{mM}$ ) as foliar spray-ing during two steps in two consecutive days in early the morning. Then, after 15 days, all of the stressed pots were sprayed with 24-EBL and $\mathrm{H}_{2} \mathrm{O}_{2}$.

The soil used in this study was sandy clay soil. Other features are given in Table 1. Due to the organic matter deficiency of the soil, all pots were fertilized with $\mathrm{N}, \mathrm{P}$, $\mathrm{K}$ fertilizers, as well as Fe, Mn, Zn fertilizers. After soil fertilization, seeds of cumin were disinfected separately by $15 \%$ sodium hypochlorite and $10 \%$ ethanol for $2 \mathrm{~min}$, then, they were rinsed three times with distilled water. For faster germination, sterilized washed seeds were soaked in water for $24 \mathrm{hrs}$. Thus, a large amount of seed phenols that prevent germination, were washed away. Then, sterilized seeds were planted in the drainage plastic pots of $30 \mathrm{~cm}$ in height and three $\mathrm{kg}$ soil. For each pot, ten seeds per pot were planted at a depth of 1-2 cm and after emergence of seedlings; four plants remained to apply the different treatments under greenhouse condition with day and night temperatures at 16 and $28{ }^{\circ} \mathrm{C}$ in the greenhouse, respectively. Given that research into cumin has showed that at high temperatures, a number of flowers lacking an ovary (male flower) are formed, the greenhouse temperature was maintained using ventilation and cooling system (Rahimian, 1990). Until the fifth week (the beginning of the reproductive stage), irrigation of all plants was carried out with water and according to the needs of the plants for irrigation. During the experiment and at different stages of the plant growth, the biochemical and physiological characteristics such as proline content, malondialdehyde, total protein concentration and the antioxidant enzymes of catalase, superoxide dismutase and ascorbate peroxidase were measured in the shoot and root.

\section{Antioxidant Enzymes Activity Assay \\ Enzyme Extractions and Measurements Catalase, Ascorbate peroxidase and Super oxide dismutase.}

To extract antioxidant enzymes, five $g$ of fresh root tissue and five $\mathrm{g}$ of fresh leaves from each treatment were weighed, and in a porcelain mortar containing $5 \mathrm{ml}$ of $0.05 \mathrm{M} \mathrm{HCl}$-Tris buffer ( $\mathrm{pH} 7.5$ ), were completely pulverized in the ice bath for $30 \mathrm{~min}$. The 
homogeneous mixture was centrifuged for $20 \mathrm{~min}$ at $10,000 \mathrm{pm}$, and the surfactant was used at $4{ }^{\circ} \mathrm{C}$ for enzyme assay (Zelinova et al., 2013). The catalase activity (CAT; EC 1.11.1.6) was assayed by absorption reduction at $240 \mathrm{~nm}$ via catabolization of $\mathrm{H}_{2} \mathrm{O}_{2}$. The activity of ascorbate peroxidase enzyme was also assayed by observing the ascorbate oxidation rate at $290 \mathrm{~nm}$ using the method by Kaya et al., (2019) and the activity of the superoxide dismutase enzyme using the method by Beauchamp and Fridovich (1976), and the changes in the absorbance of the reaction solution compared to the control were measured by the spectrophotometer (Spekol2000) at $560 \mathrm{~nm}$ and the activity of the superoxide dismutase enzyme was expressed as U mg per protein.

\section{Method of proline extraction and assay}

Proline was assayed according to the method by Bates et al., (1973) in which $0.1 \mathrm{~g}$ of the fresh root tissue and shoot were separately homogenate by $10 \mathrm{ml}$ of $3 \%$ sulfosalicylic acid solution and filtered by filtered by filter paper after $48 \mathrm{~h}$, followed by one $\mathrm{mL}$ of the solution was removed and, after mixing with two $\mathrm{mL}$ of glacial acetic acid was placed in a Bain Marie at $100{ }^{\circ} \mathrm{C}$ for one hour and immediately cooled. Then, four $\mathrm{mL}$ of toluene were added. After $30 \mathrm{~min}$, the absorption at $520 \mathrm{~nm}$ was measured. The concentration of proline in each sample measured was calculated based on standard curve, in terms of $\mathrm{mM} / \mathrm{g}$ fresh weigh.

\section{Concentration of malondialdehyde (MDA) in leaves}

To determine the concentration of malondialdehyde in the leaves, $0.5 \mathrm{~g}$ of the fresh leaves thoroughly powdered was mixed with $20 \%$ of trichloroacetic acid 3 (TCA) solution containing $0.5 \%$ of thiobarbituric acid 4 , and then, this mixture was heated in the Bain Marie bath at $95{ }^{\circ} \mathrm{C}$ for $25 \mathrm{~min}$. The mixture was then cooled in the ice bath and, according to the method of Valentovic et al., (2006); the concentration of malondialdehyde was measured at $532 \mathrm{~nm}$.

\section{Protein Concentration}

Protein assay were performed by the method by Bradford (1976). For this purpose, $1 \mathrm{~g}$ of the shoot fresh tissue that was exposed to $0-4{ }^{\circ} \mathrm{C}$, homogenated with $5 \mathrm{~mL}$ of $0.05 \mathrm{M} \mathrm{HCl}$-Tris buffer ( $\mathrm{pH} 7.5$ ) for 30 min, and after transferring to Eppendorf tube, it was centrifuged at $1300 \mathrm{rpm}$ at $4{ }^{\circ} \mathrm{C}$ for $20 \mathrm{~min}$. One hundred (100) $\mathrm{ml}$ of the extract were mixed with five $\mathrm{mL}$ of Bradford's solution and the absorption rate was measured by spectrophotometer (Spekol2000) at $595 \mathrm{~nm}$ and the protein concentration rate was expressed in $\mathrm{mg} / \mathrm{l}$.

\section{Statistical Analysis}

Data were statistically analyzed using SAS software. One-way ANOVA analysis followed by Duncan's multiple range tests at $5 \%$ level was performed.

Table (1):Physical and chemical properties of soil used.

\begin{tabular}{lccccccc}
\hline \hline Soil texture & $\begin{array}{c}\text { Electrical } \\
\text { conductivity } \\
\left(\mathbf{d s . m ^ { - 1 } )}\right.\end{array}$ & $\mathbf{p H}$ & $\begin{array}{c}\text { Available } \\
\mathbf{p h o s p h o r u s} \\
(\mathbf{p p m})\end{array}$ & $\begin{array}{c}\text { Available } \\
\text { potassium } \\
(\mathbf{p p m})\end{array}$ & $\begin{array}{c}\text { Sodium } \\
(\mathbf{p p m})\end{array}$ & $\begin{array}{c}\text { Calcium } \\
(\mathbf{p p m})\end{array}$ & $\begin{array}{c}\text { Magnesium } \\
(\mathbf{p p m})\end{array}$ \\
\hline sandy clay soil & 0.42 & 7.9 & 6.8 & 150 & 2.34 & 1365 & 105 \\
\hline \hline
\end{tabular}

\section{RESULTS}

\section{Proline Variations in the Shoot}

The results of analysis of variance showed that the effect of drought stress, 24-epibrassinosteroid, as well as the interaction of drought stress and 24-brassinosteroids (24-EBL) on the mean proline content in the shoot was significant different (Table 2). According to a comparison of the mean data, the highest mean proline in the shoot $\left(10.33 \mathrm{mMol}_{\mathrm{gFW}}{ }^{-1}\right)$ was related to spraying of 24-epibrassionsteroids, which showed a $12 \%$ increase compared to the optimum irrigation treatment (Table3). The results of effect of 24epibrassinosteroid on plant growth under drought stress showed that the highest proline content in the root

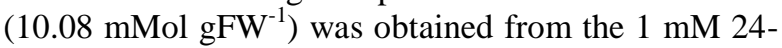
epibrassinosteroid and 50\% FC of drought stress (Table3).

\section{Proline Variations in the Root}

The proline content of root tissues showed significant differences among the different levels of drought stress as responses of exogenous application of 24-epibrassinosteroid $(\mathrm{Br})$ and hydrogen peroxide $\left(\mathrm{H}_{2} \mathrm{O}_{2}\right)$ at $1 \%$ level (Table 2). The highest proline content in the root tissues was obtained under severe stress $(50 \%$ of $\mathrm{FC})$ at a rate of $9.95 \mathrm{mMol} \mathrm{gFW}^{-1}$ and the lowest $(9.52 \mathrm{mMol} \mathrm{gFW}-1)$ was related to optimal irrigation (100\% FC). Among the different concentrations of 24-epibrassinosteroid, the highest proline content of the root $\left(10.08 \mathrm{mMol} \mathrm{gFW}^{-1}\right)$ was related to the concentration of $1 \mathrm{mM}$ 24-EBL. Moreover, the concentration of $1 \mathrm{mM}$ of $\mathrm{H}_{2} \mathrm{O}_{2}$ also increased the mean proline content of the root at a rate of $9.84 \mathrm{mML}^{-1} \mathrm{FW}$ (Table 3 ). The results of a comparison of the mean interactions of applying 24-epibrassinosteroid under drought stress conditions indicated that the highest proline content in the root with $9.84 \mathrm{mMol} \mathrm{gFW}^{-1}$ was related to the concentration of $1 \mathrm{mM} 24$-epibrassinosteroid and severe drought stress $(50 \%$ FC) (Table 4).

\section{Catalase Activity (CAT) Variations in the Shoot and Root}

According to the results obtained, the effect 24epibrassinosteroid hormone and hydrogen peroxide, on the root catalase, as well as the interaction of both 24epibrassinosteroid and hydrogen peroxide on the activity of shoot catalase was recorded table 2 . The data showed significant $(p \leq 0.05)$ effect in which with increasing drought stress, the root catalase was 
reduced, while spraying with 24-epibrassinosteroid at $1 \mathrm{mM}$ in under control conditions, mild stress (75\% FC) and severe stress $(50 \%$ FC) increased the root catalase was detected table 4 . The catalase enzyme of the shoot was also affected by drought stress and spraying with either brassinosteroids or hydrogen peroxide was highly affected (Table 2). The highest activity of this enzyme was obtained at severe stress $(50 \%$ FC) condition and a concentration of $1 \mathrm{mM} 24$-epibrassinosteroid and the lowest was related to the desirable irrigation (100\% FC) and no spraying with brassinosteroids table 3 . The results of interactions of drought stress, 24-epibrassinosteroid $\times$ hydrogen peroxide showed the highest content of the shoot catalase (1.31mM $\mathrm{H}_{2} \mathrm{O}_{2} \mathrm{~min}^{-1}$ ) concentration of $0.5 \mathrm{mM}$ hydrogen peroxide and $1 \mathrm{mM} 24$-epibrassino-steroid at $50 \%$ of FC (Figure 1).

\section{Ascorbate Peroxidase (APX) Activity in the Shoot and Root}

Variations in PAX activity, in response to drought stress, spraying with hydrogen peroxide or 24epibrassinosteroid hormone were significant differences on the shoot and root tissues (Table 2). The highest activity of the ascorbate peroxidase enzyme was recorded in the root $\left(0.70 \mathrm{mM} \mathrm{H} \mathrm{H}_{2} \mathrm{O}_{2} \mathrm{~min}^{-1}\right)$ under the third level of drought stress $(50 \%$ FC), which showed an increased by $35 \%$ compared to the control (100\% FC) (Table 3).

Furthermore, the highest level of APX in the shoot (0.80) was recorded at the third level of drought stress (50\% FC), which showed an increase by $30 \%$ compared to the control (100\% FC) (Table 3). However, the different levels of 24-epibrassinosteroid recorded the highest APX in the shoot $\left(0.83 \mathrm{mM} \mathrm{H}_{2} \mathrm{O}_{2}\right.$ $\min ^{-1}$ ) at $1 \mathrm{mM} 24-E B L$ when applied exogenous. The highest activity of APX in the shoot $\left(0.72 \mathrm{mM} \mathrm{H}_{2} \mathrm{O}_{2}\right.$ $\mathrm{min}^{-1}$ ) was detected when plants treated with $1 \mathrm{mM}$ hydrogen peroxide. At this $\mathrm{H}_{2} \mathrm{O}_{2}$ level, APX was the highest when compared to the plants treated with 24epibrassinosteroid (Table 3).

\section{Superoxide Dismutase (SOD) Activity in the Shoot and Root}

SOD, in response to different treatment under drought stress conditions, confirms the effects of drought stress, and spraying with either (Table 2). According to our study, the highest activity of SOD in the root $\left(0.48 \mathrm{umg}\right.$ protein $\left.{ }^{-1}\right)$ was detected under severe drought stress (50\% FC), and represented by $37 \%$ increase compared to the control (100\% $\mathrm{FC})$. Moreover, the highest amount of SOD in the root (0.47) was obtained when $1 \mathrm{mM}$ hydrogen peroxide was applied. In the evaluation of the activity of this enzyme in the shoot, the highest value recorded was $0.8 \mathrm{umg}$ protein $^{-1}$ at $1 \mathrm{mM}$ 24-epibrassinosteroid (Table 3 ). In meantime, the application of brassinosteroids showed that the highest SOD value in the root tissue (0.64 umg protein $\left.{ }^{-1}\right)$ was recorded under severe drought stress and $1 \mathrm{mM}$ brassinosteroids (Table 4). In addition, the interaction of drought stress and 24-epibrassinosteroid on the activity of superoxide dismutase in the shoot showed that the highest mean activity of this enzyme $\left(0.91 \mu \mathrm{mg}\right.$ protein $\left.^{-1}\right)$ was related to $50 \% \mathrm{FC}$ and one $\mathrm{mM}$ 24-epibrassinosteroid (Table 4).

\section{Level of Malondialdehyde (MDA) In the Shoot}

The exogenous application of 24-epibrassinosteroid, as well as both combination of brassinosteroids and hydrogen peroxide on MDA in the shoot was significantly different (Table 2). Moreover, for shoot tissue combination of 24-epibrassinosteroid and hydrogen peroxide under severe drought stress on MDA level was also significantly different at $5 \%$ level (Table 2). In general, drought stress significantly increased the malondialdehyde content in the leaves compared to the control application of 24-epibrassinosteroid (Table 3). According to our data obtained for shoot tissues the highest MDA (0.45) was recorded under $50 \%$ of FC and $0.5 \mathrm{mM}$ brassinosteroids and 1 $\mathrm{mM}$ hydrogen peroxide (Figure 2).

\section{Total Protein assay}

The effects of exogenous hormonal treatment and $\mathrm{H}_{2} \mathrm{O}_{2}$ on total protein content of cumin plant, grown under drought stress, were significant different $(p \leq$ 0.05 ) were significant (Table 2). Drought stress showed a decreased in protein content of cumin. The highest protein content was observed for the control plant $(100 \%$ FC) and those treated with $1 \mathrm{mM} 24-$ epibrassinosteroid hormone (11.40 $\mathrm{mg} \mathrm{L}^{-1}$ ) (Table 3)

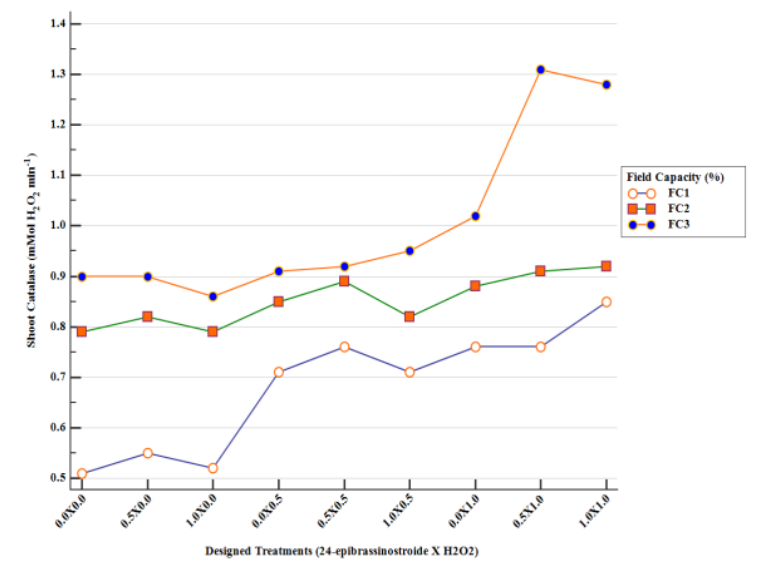

Figure (1): Interaction of drought stress, 24-epibrassinosteroid and $\mathrm{H}_{2} \mathrm{O}_{2}$ on the shoot catalase; $\mathrm{FC} 1,100 \% ; \mathrm{FC} 2,75 \%$ and $\mathrm{FC} 3$, $50 \%$.

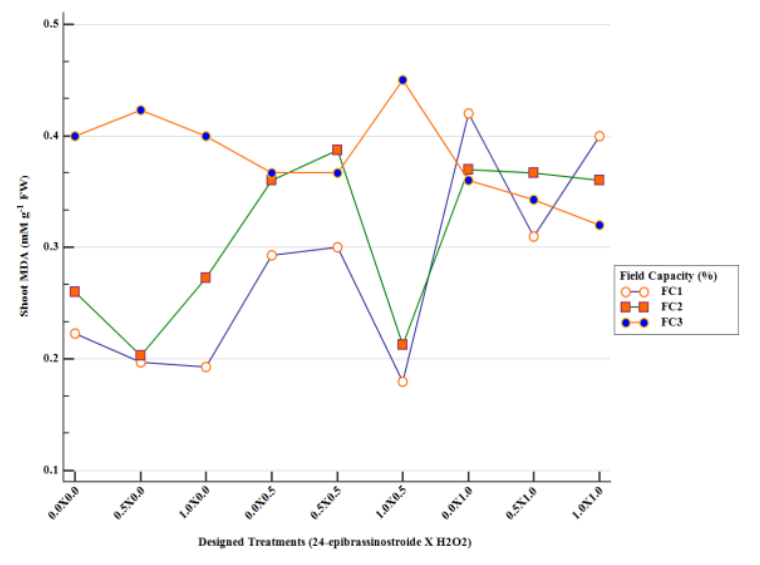

Figure (2): Interaction of drought stress, 24-epibrassinosteroid and $\mathrm{H}_{2} \mathrm{O}_{2}$ on the shoot MDA; FC1, $100 \%$; FC2, $75 \%$ and $\mathrm{FC} 3,50 \%$. 
Table (2): Analysis variance of drought stress, 24-epibrassinolide and hydrogen peroxide on experimented traits.

\begin{tabular}{|c|c|c|c|c|c|c|c|c|c|c|}
\hline \multirow{2}{*}{$\begin{array}{l}\text { Different } \\
\text { treatments }\end{array}$} & \multirow{2}{*}{ df } & \multicolumn{2}{|c|}{$\begin{array}{l}\text { Proline Content } \\
\left(\mathbf{m M o l} \mathbf{g F W}^{-1}\right)\end{array}$} & \multirow{2}{*}{$\begin{array}{c}\text { CAT } \\
\begin{array}{c}\text { Activity } \\
\text { in }\end{array} \\
\text { Root }\end{array}$} & \multicolumn{2}{|c|}{ APX activity } & \multicolumn{2}{|c|}{ SOD activity } & \multirow{2}{*}{$\begin{array}{c}\text { Leaf } \\
\text { MDA } \\
\text { content } \\
\left(\mathbf{m M} \text { gFW }^{-1}\right)\end{array}$} & \multirow{2}{*}{$\begin{array}{l}\text { Soluble } \\
\text { protein } \\
\text { content }\end{array}$} \\
\hline & & Shoot & Root & & Shoot & Root & Shoot & Root & & \\
\hline Drought (D) & 2 & $12.32^{* *}$ & $1.0^{* *}$ & $0.57^{\circ *}$ & $0.37^{\circ \bullet}$ & $0.48^{\circ \bullet}$ & $0.26^{\circ}$ & $0.22^{\circ}$ & $0.06^{* *}$ & $0.42^{* *}$ \\
\hline $\mathbf{H}_{2} \mathbf{O}_{2}$ & 2 & $0.15^{* *}$ & $0.32^{* *}$ & $0.03^{\circ}$ & $0.03^{* \bullet}$ & $0.003^{\mathrm{ns}}$ & $0.009^{\circ}$ & $0.01^{\circ}$ & $0.011^{*}$ & $0.047^{\mathrm{ns}}$ \\
\hline 24-EBL & 2 & $1.69^{* *}$ & $2.97^{* *}$ & $0.29^{* * *}$ & $0.53^{* *}$ & $0.33^{* *}$ & $0.45^{* *}$ & $0.14^{* *}$ & $0.48^{* *}$ & $1.35^{* *}$ \\
\hline$D \times 24-E B L$ & 4 & $0.32^{* *}$ & $0.28^{* *}$ & $0.04^{* *}$ & $0.009^{\mathrm{ns}}$ & $0.004^{\mathrm{ns}}$ & $0.013^{* *}$ & $0.028^{* *}$ & $0.04^{* *}$ & $0.15^{* *}$ \\
\hline $\mathrm{D} \times \mathrm{H}_{2} \mathbf{O}_{2}$ & 4 & $0.012^{\text {ns }}$ & $0.029^{\mathrm{ns}}$ & $0.001^{\mathrm{ns}}$ & $0.006^{\mathrm{ns}}$ & $0.009^{\mathrm{ns}}$ & $0.001^{\mathrm{ns}}$ & $0.0004^{\mathrm{ns}}$ & $0.004^{\mathrm{ns}}$ & $0.03^{\mathrm{ns}}$ \\
\hline 24-EBL $\times \mathrm{H}_{2} \mathrm{O}_{2}$ & 4 & $0.012^{\mathrm{ns}}$ & $0.047^{\mathrm{ns}}$ & $0.0006^{\mathrm{ns}}$ & $0.001^{\mathrm{ns}}$ & $0.01^{\mathrm{ns}}$ & $0.0006^{\mathrm{ns}}$ & $0.0008^{\mathrm{ns}}$ & $0.008^{*}$ & $0.023^{\text {ns }}$ \\
\hline $\mathrm{D} \times 24-\mathrm{EBL} \times \mathrm{H}_{2} \mathrm{O}_{2}$ & 8 & $0.021^{\mathrm{ns}}$ & $0.021^{\mathrm{ns}}$ & $0.001^{\mathrm{ns}}$ & $0.0008^{\mathrm{ns}}$ & $0.015^{\mathrm{ns}}$ & $0.0022^{\mathrm{ns}}$ & $0.0003^{\mathrm{ns}}$ & $0.007^{*}$ & $0.029^{\text {ns }}$ \\
\hline Error & 54 & 0.008 & 0.052 & 0.0068 & 0.004 & 0.01 & 0.0022 & 0.001 & 0.003 & 0.021 \\
\hline $\mathrm{CV}(\%)$ & - & 0.93 & 2.35 & 10.43 & 10.11 & 16.76 & 7.01 & 8.43 & 18.02 & 1.30 \\
\hline
\end{tabular}

$\mathrm{ns}, *, * *$, non-significance and significant at the $5 \%$ and $1 \%$ level of probability, respectively.

Table (3): The effects of drought stress, 24-epibrassinosteroid (24-EBL) and hydrogen peroxide $\left(\mathrm{H}_{2} \mathrm{O}_{2}\right)$ on measured experimented traits (Ascorbate peroxidase (APX), Proline content, Superoxide dismutase (SOD), MDA.

\begin{tabular}{|c|c|c|c|c|c|c|c|c|c|}
\hline Treatments & $\begin{array}{c}\text { Applied } \\
\text { Conditions }\end{array}$ & $\begin{array}{l}\text { Root } \\
\text { APX } \\
\end{array}$ & $\begin{array}{l}\text { Shoot } \\
\text { APX } \\
\left.\operatorname{nin}^{-1}\right)\end{array}$ & $\begin{array}{c}\text { Root } \\
\text { proline } \\
\left(\mathrm{mMol} \mathrm{gFW}^{-1}\right)\end{array}$ & $\begin{array}{l}\text { Shoot } \\
\text { proline }\end{array}$ & $\begin{array}{l}\text { Root SOD } \\
\left(\text { Umg protein }^{-1}\right)\end{array}$ & $\begin{array}{l}\text { Shoot } \\
\text { SOD }\end{array}$ & $\begin{array}{l}\text { Shoot } \\
\text { MDA } \\
\left(\mathrm{mM} \mathrm{gr}^{-1} \mathrm{FW}\right)\end{array}$ & $\begin{array}{l}\begin{array}{l}\text { Total } \\
\text { protein }\end{array} \\
\left(\mathrm{mg} \mathrm{g}^{-1}\right)\end{array}$ \\
\hline \multirow{3}{*}{$\begin{array}{l}\text { Drought stress } \\
\text { (FC \%) }\end{array}$} & 100 & $0.45^{\mathrm{b}}$ & $0.56^{\mathrm{c}}$ & $9.52^{\mathrm{c}}$ & $9.51^{\mathrm{c}}$ & $0.30^{\mathrm{c}}$ & $0.58^{\mathrm{c}}$ & $0.27^{\mathrm{c}}$ & $11.19^{\mathrm{a}}$ \\
\hline & 75 & $0.67^{\mathrm{a}}$ & $0.71^{\mathrm{b}}$ & $9.69^{b}$ & $9.84^{b}$ & $0.36^{\mathrm{b}}$ & $0.66^{\mathrm{b}}$ & $0.31^{\mathrm{b}}$ & $11.16^{\mathrm{a}}$ \\
\hline & 50 & $0.70^{\mathrm{a}}$ & $0.80^{\mathrm{a}}$ & $9.95^{\mathrm{a}}$ & $10.18^{\mathrm{a}}$ & $0.48^{\mathrm{a}}$ & $0.77^{\mathrm{a}}$ & $0.37^{\mathrm{a}}$ & $10.96^{\mathrm{b}}$ \\
\hline \multirow{4}{*}{$\begin{array}{c}\text { 24-EBL } \\
\text { concentration } \\
(\mathrm{mMol})\end{array}$} & 0.0 & $0.50^{\mathrm{c}}$ & $0.55^{\mathrm{c}}$ & $9.42^{c}$ & $9.83^{\mathrm{c}}$ & $0.31^{\mathrm{c}}$ & $0.54^{\mathrm{c}}$ & $0.37^{\mathrm{a}}$ & $10.87^{\mathrm{c}}$ \\
\hline & 0.5 & $0.60^{\mathrm{b}}$ & $0.68^{\mathrm{b}}$ & $9.67^{b}$ & $10.00^{\mathrm{b}}$ & $0.36^{\mathrm{b}}$ & $0.67^{\mathrm{b}}$ & $0.32^{\mathrm{b}}$ & $11.13^{\mathrm{b}}$ \\
\hline & 1.0 & $0.72^{\mathrm{a}}$ & $0.83^{\mathrm{a}}$ & $10.08^{\mathrm{a}}$ & $10.33^{\mathrm{a}}$ & $0.46^{\mathrm{a}}$ & $0.80^{\mathrm{a}}$ & $0.28^{\mathrm{c}}$ & $11.31^{\mathrm{a}}$ \\
\hline & 0.0 & $0.60^{\mathrm{a}}$ & $0.65^{\mathrm{b}}$ & $9.63^{\mathrm{b}}$ & $10.00^{\mathrm{a}}$ & $0.36^{\mathrm{b}}$ & $0.65^{\mathrm{b}}$ & $0.34^{\mathrm{a}}$ & $11.07^{\mathrm{a}}$ \\
\hline \multirow{2}{*}{$\begin{array}{c}\mathrm{H}_{2} \mathrm{O}_{2} \\
\text { concentration }\end{array}$} & 0.5 & $0.62^{\mathrm{a}}$ & $0.69^{\mathrm{ab}}$ & $9.69^{\mathrm{b}}$ & $10.02^{\mathrm{a}}$ & $0.38^{b}$ & $0.68^{\mathrm{a}}$ & $0.32^{\mathrm{ab}}$ & $11.09^{\mathrm{a}}$ \\
\hline & 1.0 & $0.60^{\mathrm{a}}$ & $0.72^{\mathrm{a}}$ & $9.84^{\mathrm{a}}$ & $10.14^{\mathrm{a}}$ & $0.47^{\mathrm{a}}$ & $0.68^{\mathrm{a}}$ & $0.31^{\mathrm{b}}$ & $11.15^{\mathrm{a}}$ \\
\hline
\end{tabular}

Similar letters in each column shows non-significant difference according to Duncan's Multiple Range tests in 5\% level of probability.

Table (4): Interaction effect of drought and 24- epibrassinosteroide on proline content, root catalase, supper oxide dismutase (SOD) and total protein content of cumin plant.

\begin{tabular}{|c|c|c|c|c|c|c|c|}
\hline \multirow{2}{*}{$\begin{array}{l}\text { 24-EBL } \\
\text { Concentration } \\
(\mathrm{mM})\end{array}$} & \multirow{2}{*}{$\begin{array}{c}\text { Applied } \\
\text { Drought } \\
\text { Conditions } \\
(\mathrm{FC} \%)\end{array}$} & Shoot proline & Root proline & \multirow{2}{*}{$\begin{array}{l}\text { Root catalase } \\
\left(\mathrm{mM} \mathrm{H}_{2} \mathrm{O}_{2} \mathrm{~min}^{-1}\right)\end{array}$} & \multicolumn{2}{|c|}{ SOD $\left(\mu \mathrm{mg}\right.$ protein- $\left.\mathbf{1}^{-1}\right)$} & \multirow{2}{*}{$\begin{array}{c}\text { Total protein } \\
\left(\mathrm{mg} \mathrm{g}^{-1}\right) \\
\end{array}$} \\
\hline & & \multicolumn{2}{|c|}{$\left(\mathrm{mMol} \mathrm{gFW}^{-1}\right)$} & & Root & Shoot & \\
\hline \multirow{3}{*}{0.0} & 100 & $9.13^{\mathrm{c}}$ & $9.03^{\mathrm{c}}$ & $0.50^{\mathrm{c}}$ & $0.27^{\mathrm{b}}$ & $0.44^{\mathrm{c}}$ & $10.94^{\mathrm{b}}$ \\
\hline & 75 & $9.63^{\mathrm{b}}$ & $9.41^{\mathrm{b}}$ & $0.74^{\mathrm{b}}$ & $0.32^{\mathrm{ab}}$ & $0.57^{\mathrm{b}}$ & $11.08^{\mathrm{a}}$ \\
\hline & 50 & $10.76^{\mathrm{a}}$ & $9.84^{\mathrm{a}}$ & $0.81^{\mathrm{a}}$ & $0.37^{\mathrm{a}}$ & $0.64^{\mathrm{a}}$ & $10.58^{\mathrm{c}}$ \\
\hline \multirow{3}{*}{0.5} & 100 & $9.42^{\mathrm{c}}$ & $9.48^{\mathrm{c}}$ & $0.69^{\mathrm{c}}$ & $0.30^{\mathrm{b}}$ & $0.55^{\mathrm{c}}$ & $11.23^{\mathrm{a}}$ \\
\hline & 75 & $9.82^{\mathrm{b}}$ & $9.65^{\mathrm{b}}$ & $0.81^{\mathrm{b}}$ & $0.36^{\mathrm{b}}$ & $0.66^{\mathrm{b}}$ & $11.10^{\mathrm{b}}$ \\
\hline & 50 & $10.77^{\mathrm{a}}$ & $9.89^{\mathrm{a}}$ & $0.90^{\mathrm{a}}$ & $0.44^{\mathrm{a}}$ & $0.79^{\mathrm{a}}$ & $11.07^{\mathrm{b}}$ \\
\hline \multirow{3}{*}{1.0} & 100 & $10.01^{\mathrm{c}}$ & $10.06^{\mathrm{b}}$ & $0.75^{\mathrm{c}}$ & $0.35^{\mathrm{c}}$ & $0.76^{\mathrm{b}}$ & $11.40^{\mathrm{a}}$ \\
\hline & 75 & $10.07^{\mathrm{b}}$ & $10.04^{\mathrm{b}}$ & $0.82^{\mathrm{b}}$ & $0.41^{\mathrm{b}}$ & $0.76^{\mathrm{b}}$ & $11.30^{\mathrm{b}}$ \\
\hline & 50 & $10.91^{\mathrm{a}}$ & $10.15^{\mathrm{a}}$ & $1.10^{\mathrm{a}}$ & $0.64^{\mathrm{a}}$ & $0.91^{\mathrm{a}}$ & $11.24^{\mathrm{c}}$ \\
\hline
\end{tabular}

Similar letters in each column shows non-significant difference according to Duncan's Multiple Range tests in 5\% level of probability 


\section{DISCUSSION}

Currently, due to the expansion of the arid and semiarid areas as well as the limited availability of water resources, identifying and selecting resistant cultivars to water-deficit stress is necessary to minimize the future problems of the world to provide foods. In the present study, the concentrations of two signaling compounds of $\mathrm{H}_{2} \mathrm{O}_{2}$ and brassinosteroid in the treated plants under drought stress conditions were used to reduce oxidative damage caused by water deficit and adaptation to stress conditions. The results of this study showed that drought stress (control, 75\% FC, 50\% FC), especially severe stress ( $50 \% \mathrm{FC})$, increased the proline content in the shoot and root (Tables 2 and 3). Cumin under drought stress conditions by storing the osmotic regulating agents such as proline confronted with drought stress (Safari et al., 2015). The results of table 2 support this claim. The proline accumulation in the cell is influenced by the use of 24-epibrassinosteroid, due to the effect of increasing this phytohormone on the enzymes of delta 1-pyrroline-5carboxylate synthetase (P5CS) and pyrroline-5carboxylate reductase (P5CR). Plant hormones contain chemical messages in response to environmental factors, and it can be said that during drought stress, the accumulation of metabolites such as proline and osmotic regulators is influenced by plant hormones (Mousavi et al., 2010). The results were consistent with the results by Neveen et al., (2012) and Sekmen et al., (2014). They also observed that with decreasing irrigation water and applying stress, the proline content in plant tissues increased.

The destruction of cell membranes is known as one of the direct consequences of water deficit. A large amount of toxic substance, including MDA, is produced in plants under drought stress conditions. The reason for this phenomenon is that drought stress eliminates the permeability balance of the plasma membrane of plants (Iqra and Naveela, 2013). In the present study, reducing the accumulation of malondialdehyde in plants treated with 24-epibrassinosteroid and $\mathrm{H}_{2} \mathrm{O}_{2}$ along with stress is likely to indicate a decrease in the lipid peroxidation and a greater survival of the membrane under stress conditions. Increasing MDA in water-deficit stress in plants such as olive (Petridisa et al., 2012), corn (Valentovič et al., 2006), alfalfa (Antolín et al., 2010) and wheat (Keyvan, 2010; Moaveni, 2011) have been reported, which support the results of this study. The plants treated with epibrassinosteroid under stress conditions efficiently eliminate oxygen free radicals compared to the same plants without the 24epibrassinosteroid. Therefore, cell damage is reduced by 24 -epibrassinosteroid and hydrogen peroxide in cumin (Table 3).

Under stress conditions, reducing protein concentrations is a common symptom of oxidative stress, which is often seen in the plants treated with drought stress (Duran et al., 2017). In the present study, with increasing drought stress, the total protein content was reduced (Table 3 ). Reducing the total protein content of the plant treated with drought stress is in fact due to free radicals produced under stress conditions, which is consistent with the findings of studies by Raza et al., (2013) on okra plant, Iqbal and Ashraf (2013) on rapeseed plant, Shahin et al., (2010) on apple fruit, and Asim Masood et al., (2016) on beans. The interaction of hydrogen peroxide and drought stress in cumin plant increased the protein content of the leaves, which is consistent with the results by Laxa et al., (2019) and Mohamed et al., (2012). They suggested that drought stress initially produced ABA, which increased the production of reactive oxygen species and, which by decreasing the protein content, promoted the expression of antioxidant system and their activity.

Barazesh et al., (2017) reported that the treatment of spermine and epibrassinolid hormones significantly increased the activities of DNA and RNA polymerase and resulted in the formation of DNA and RNA in pistachio tree. Increased protein synthesis has been observed in various plants treated with brassinosteroids. Neveen et al., (2015) also argued that 24epibrassinosteroid resulted in an increase in the HSP protein contents under water-deficit stress, which increased the resistance of plants to stress. These findings are consistent with the results of this study. The results of this study suggest that the use of brassinosteroids and its repetition during growth can be recommended in cumin plants. However, it is obvious that further research is needed to clarify the molecular mechanism of the activity of brassinosteroids under stress conditions.

The protective and antioxidant role of brassinosteroids is well proven against some abiotic stresses (Vardhini, 2013; Peres et al., 2019). In this study, it was found that the use of 24-epibrassinosteroid by reducing the stress effects resulted in a significant increase in proline, the enzymes of SOD, APX and $\mathrm{CAT}$ in the shoot and root, and total protein content under severe stress conditions (\%50 FC) and mild stress (75\% FC) (Table 2). By increasing the level of antioxidants (SOD, APX and CAT) in response to drought stress in cumin plants treated with brassinosteroids and hydrogen peroxide to improve the growth process, it may be suggested that this antioxidant system, at least in part, be responsible for the resistance of cumin plants to drought stress.

Antioxidant enzymes play an important role against the oxidative stress caused by adverse environmental conditions. In the present study, with increasing drought stress, the CAT activity of the root had a significant decrease compared to the control treatment. However, the spraying of plants with brassinosteroids and hydrogen peroxide could increase the level of this enzyme and thereby reducing the harmful effects of reactive oxygen species (ROS), so that the activity of this enzyme in the root tissue under severe stress conditions and spraying with one $\mathrm{mM}$ brassinosteroid reached at a rate of $1.10 \mathrm{mM} \mathrm{H}_{2} \mathrm{O}_{2} \min ^{-1}$ (Table 4). A decrease in and deactivation of the CAT enzyme under osmotic stress conditions may be due to inhibiting the enzyme synthesis or inactivation of the enzyme by the radical, peroxide and hydroxyl oxygen (Hosseini 
Boldaji et al., 2012). The SOD enzyme also plays a major role in protecting plant cells against oxidative stress, because the enzyme can convert the superoxide radical into hydrogen peroxide and molecular oxygen.

In this study, the highest level of the root superoxide dismutase was related to the severe drought stress treatment $\left(50 \%\right.$ FC) $\left(0.48 \mathrm{Umg}\right.$ protein $\left.^{-1}\right)$, which showed a $37 \%$ increase compared to the control treatment. Increasing the SOD activity under drought stress can be due to an increase in the superoxide radical or a defense mechanism against oxidative stress in plants (Mirzaee et al., 2013).

With the exogenous application of $\mathrm{H}_{2} \mathrm{O}_{2}$ at low doses (0.5 and $1 \mathrm{mM})$, along with the application of 24-EBL during the experiment, the antioxidant activity of enzymes of catalase, ascorbate peroxidase and superoxide dismutase increased under drought stress conditions in the shoot and root (Table 2). Such a conclusion has been reported by other researchers (Debnath et al., 2019; Mirzaee et al., 2013; Marcin ska et al., 2013).

Considering the importance of antioxidant enzymes in scavenging free oxygen radicals and preventing oxidative stress caused by water deficit, it seems that increased proline activity, accompanied by increasing the activity of superoxide dismutase in the shoot and root, caused to reduce the negative effects of oxidative stress caused by free oxygen radicals, and thus cumin showed greater resistance to drought stress. The lower increase of malondialdehyde in the shoot during the experiment also supported this conclusion (Table 3).

\section{CONCLUSION}

According to the results of the present study, drought stress had adverse effects on the physiological characteristics of Cumin plant. Plants; however, the use of 24-epibrassinosteroids and hydrogen peroxide could improve these adverse effects and increase tolerance of this plant to drought stress conditions. Improvement of drought tolerance under the conditions of this experiment could be due to (a) improvement of antioxidant enzyme activity and protection against oxidative stress, (b) reduction MDA content and proline accumulation. Therefore, to offset as least some of the harmful effects of drought stress on cumin, spraying of hydrogen peroxide and 24- epibrassinosteroids before the onset of stress and its recurrence within two weeks thereafter can be recommended as a a management tool to improve the growth and stress tolerance of cumin in arid and semi-arid regions.

\section{REFERENCES}

ANTOLÍN, M.C., I. MURO., AND M. SÁNCHEZDÍAZ. 2010. Application of sewage sludge improves growth, photosynthesis and antioxidant activities of modulated alfalfa plants under drought conditions. Environmental and Experimental
Botany, 68: 75-82.

ASIM MASOOD, M., R.K. IQBAL., F. MEHAR., MOHDASGHER., S.P. TASIR., A.K. NAFEES. 2016. Involvement of ethylene in gibberellin acidinduced sulfur assimilation, photosynthetic responses, and alleviation of cadmium stress in mustard. Plant Physiology and Biochemistry, 104: $1-10$.

BAHRAMINEJAD, A., G. MOHAMMADI-NEJAD., AND M. ABDUL KHADIR. 2011. Genetic diversity evaluation of Cumin (Cumin cyminum L.) based on phenotypic characteristics. Australian Journal of Agricultural Research, 5: 304-310.

BARAZESH, F., H. OLOUMI., F. NASIBI., KALANTARI., AND M. KHOSROW. 2017. Effect of Spermine, Epibrassinolid and their interaction on inflorescence buds and fruits abscission of pistachio tree (Pistacia vera L.), "Ahmad-Aghai" cultivar. Banat's Journal of Biotechnology, 8(16): 105-115.

BATES, L. S., R. P. WALDRAN., AND I. D. TEARE. 1973. Rapid determination of free proline for water studies. Plant Soil, 39: 205-208.

BEAUCHAMP, C., AND I. FRIDOVICH. 1976. Superoxide dismutase: improved assays and an assay applicable to acrylamide gels. Anal Biochem. 44(1): 276-87.

BENHMIMOU, A., M. IBRIZ., AL FAÏZ, C., GABOUN, F., SHAIMI, N., AMCHRA, F.Z., LAGE, M. 2018. Effects of water stress on growth, yield, quality and physiological responses of two stevia (Stevia rebaudiana Bertoni) varieties in Rabat region, Morocco. Asian J Agri \& Biol, 6(1): 21-34.

BHATTACHARJEE, S. 2012. The Language of Reactive Oxygen Species Signaling in Plants. Journal of Botany. 1-22.

BRADFORD, M.M. 1976. A rapid and sensitive method for the quantitation of microgram quantities of protein utilizing the principle of protein-dye binding. Anal.Biochem. 72: 248-254.

CAVERZAN, A., A. CASASSOLA., S.P. BRAMMER. 2016. Antioxidant responses of wheat plants under stress. Genetics and Molecular Biology, 39(1): $1-6$.

CHOUDHURY, F.K., RIVERO, R.M., BLUMWALD, E., MITTLER, R. 2017. Reactive oxygen species, abiotic stress and stress combination. The plant journal, 90: 856-867.

DAGHINO, S., E. MARTIN., S. PEROTTO.2016. Model systems to unravel the molecular mechanisms of heavy metal tolerance in the ericoid mycorrhizal symbiosis. Mycorrhiza, 26(4): 263274.

DEBNATH, M., N. ASHWATH, D.J. MIDMORE. 2019. Physiological and morphological responses to abiotic stresses in two cultivars of Stevia rebaudiana (Bert.) Bertoni. South African Journal of Botany, 123: 124-132.

DURAN, M.I., C. GONZÁleZ., A. ACOSTA., A.F. OLEA., K. DÍAZ., AND L. ESPINOZA. 2017. Synthesis of Five Known Brassinosteroid Analogs from Hyodeoxycholic Acid and Their Activities as Plant-Growth Regulators. Int J Mol Sci, 8:18(3). 
EINIZADE, P., H. DEHGHANI., AND M. KHODADADI. 2016. Investigation of drought stress tolerance and adaptation in iranian endemic coriander (Coriandrum sativum L.) populations. Iranian Journal of Horticultural Science, 47(2): 317-327.

FARIDUDDIN, Q., M. YUSUF., I. AHMAD., A. AHMAD 2014. Brassinosteroids and their role in response of plants to abiotic stresses. Biologia Plantarum, 58(1): 9-17.

GAO, Y., Y.K. GUO., SH. LIN., YY. FANG., G. GANGBAI. 2010. Hydrogen peroxide pretreatment alters the activity of antioxidant enzymes and protects chloroplast ultrastructure in heat-stressed cucumber leaves. Scientia Horticulturae, 126(1): 20-26.

GHOLI NEJAD, R., AS. SIROUSMEHR., AND B. FAKHERI. 2014. Effects of drought and organic fertilizers on the activity of antioxidant enzymes, photosynthetic pigments, proline and performance of borage (Borago officinalis L.). Journal of Horticultural Science, 28(3): 338-346.

HOSSEINI BOLDAJI, S. A., R. A. KHAVARINEJAD., R. HASSAN SAJEDI., H. FAHIMI., S. SAADATMAND. 2012. Water availability effects on antioxidant enzyme activities lipid peroxidation, and reducing sugar contents of alfalfa (Medicago sativa L.). Acta Physiologia Plantarum, 34: 1177 1186.

HUSSEIN, M.M., AND A.K. ALVA. 2014. Effects of Zinc and Ascorbic Acid Applicationon the Growth and Photosynthetic Pigments of Millet Plants Grown under Different Salinity. Agricultural Sciences, 5: 1253-1260.

ISHIBASHI, Y., T. TAWARATSUMIDA., K., SH. KASA., M. SAKAMOTO., N. AOKI., SH-H. ZHENG., T. YUASA., M. LWAYA-INOUE. 2012. Reactive Oxygen Species Are Involved in Gibberellin/Abscisic Acid Signaling in Barley Aleurone Cells. Plant physiology, 158(4): 17051714.

IQBAL, M., AND M. ASHRAF. 2013. Gibberellic acid mediated induction of salt tolerance in wheat plants: Growth, ionic partitioning, photosynthesis, yield and hormonal homeostasis. Environmental and Experimental Botany, 86: 76-85.

IQRA, A., AND N. NAVEELA. 2013. Effect of Waterlogging and Drought Stress in Plants. Int. J. Water Resources and Environmental Sciences, 2(2): 34-40.

KAYA, C., M. OKANT., F. UGURLAR., M.N. ALYEMENI., M. ASHRAF., P. AHMAD. 2019. Melatonin-mediated nitric oxide improves tolerance to cadmium toxicity by reducing oxidative stress in wheat plants. 225: 627- 638 .

KEYVAN, SH. 2010. The effects of drought stress on yield, relative water content, proline, soluble carbohydrates and chlorophyll of bread wheat cultivars. Journal of Animal \& Plant Sciences, 8(3): 1051-1060.

KAFI, M., M.H. RASHED MOHASSEL. A.
KOOCHEKI. 2006. Cumin (Cuminum cyminum) Production and Processing. Ferdowsi University of Mashhad press. 195.

KAFI, M., A. BORZOEE., A. SALEHI KAMANDI., A. MASOUMI., AND A. NABATI. 2009. Physiology of Environmental Stresses in Plant. Ferdowsi University of Mashhad Publication, Iran. 502.

LAXA, M., M. LIEBTHAL., W. TELMAN., K. CHIBANI., K.J. DIETZ. 2019. The Role of the Plant Antioxidant System in Drought Tolerance. Antioxidants, 8(94): 1-31.

LISAR, S.Y. S., R. MOTAFAKKERAZAD., M.M. HOSSAIN., AND I. RAHMAN. 2012. Handbook of Water stress in plants: causes, effects and responses, Water Stress, Prof. Ismail Md. Mofizur Rahman (Ed.), 1-17.

MARCIN'SKA, I., I. CZYCZYŁO-MYSZA., E. SKRZYPEK., M. FILEK., S. GRZESIAK., MT. GRZESIAK., F. JANOWIAK., T. HURA., M. DZIURKA., K. DZIURKA., A. NOWAKOWSKA., SA. QUARRIE. 2013. Impact of osmotic stress on physiological and biochemical characteristics in drought-susceptible and droughtresistant wheat genotypes. Acta Physiol Plant, 35: 451-461.

MIRZAEE, M., A. MOIENI., AND F. GHANATI. 2013. Effects of Drought Stress on the Lipid Peroxidation and Antioxidant Enzyme Activities in Two Canola (Brassica napus L.) Cultivars. J. Agr. Sci. Tech, 15: 593-602.

MOAVENI, P. 2011. Effect of water deficit stress on some physiological traits of wheat (triticum aestivum) Agricultural Science Research Journal, 1(1): $64-68$

MOGHADDAM, M., M. ALIREZAEI., Y. SALAHVARZI, AND M. GOLDANI. 2014. The effect of drought stress on some morphological and physicochemical characteristics of three cultivars of basil (Ocimum basilicum L.). Iranian Journal of Horticultural Science, 46(3): 509-521.

MOUSAVI, S.H., Z. TAYARANI-NAJARAN., M. ASGHARI., HR. SADEGHNIA. 2010. Protective effect of Nigella sativa extract and thymoquinone on serum/glucose deprivation-induced.

NEVEEN, B., T. BAHAA., A. SHAWKY., AND S. IBRAHIM. 2015. Alleviation of drought-induced oxidative stress in maize (Zea mays L.) plants by dual application of 24-epibrassinolide and spermine. Environmental and Experimental Botany, 113: $47-58$

NEVEEN, B., T. SHAWKY. 2012. 24-Epibrassinolide ameliorates the saline stress and improves the productivity of wheat (Triticum aestivum L.). Environmental and Experimental Botany. 82: 8088.

NOCTOR, G., JP. REICHHELD., CH. FOYER. 2017. ROS-related redox regulation and signaling in plants. Seminars in Cell \& Developmental Biology, 80: 3-12.

OMIDBEIGI, R. 2007. Production and processing of medicinal plants. Journal of Agricultural Knowledge and sustainable production, Astan 
Ghods Publication, 2: 438.

PERES, A.LG., J.S. SOARES., R.G. TAVARES., G. RIGHETTO., M.A.T. ZULLO., N.B. MANDAVA., M. MENOSSI. 2019. Brassinosteroids, the Sixth Class of Phytohormones: A Molecular View from the Discovery to Hormonal Interactions in Plant Development and Stress Adaptation. International journal of molecoular sciences, 20(331): 1-33.

PETRIDISA, A., I. THERIOS., G. SAMOURIS., S. ., A. GIANNAKOULA. 2012. Effect of water deficit on leaf phenolic composition, gas exchange, oxidative damage and antioxidant activity of four Greek Olive (Olea europaea L.) cultivars. Plant Physiology and Biochemistry, 60: 1-11.

QIAO, W., CH. LI., LIU. MINFAN. 2014. Cross-talk between nitric oxide and hydrogen peroxide in plant responses to abiotic stresses. Environmental and Experimental Botany, 100: 84-93.

RAHIMIAN, H. 1990. Effect of cultivation and irrigation regime on cumin growth and yield. Iranian Research Organization for Science and Technology (IROST), Khorasan.

RAZA, S.H., F. SHAFIQ, M. CHAUDHARY AND I. KHAN. 2013. Seed Invigoration with Water, Ascorbic and Salicylic Acid Stimulates Development and Biochemical Characters of Okra (Ablemoschus esculentus) under Normal and Saline Conditions. Int. J. Agric. Biol., 15: 486-492.

SAFARI, B., S.M.M MORTAZAVIAN., S.A. SADAT-NOORI., B. FOGHI. 2015. Effect of Water Stress on Yield and Yield Components of Cumin (Cuminum cyminumL.) Ecotypes. Journal of Plant Physiology and Breeding. 5(2): 51-61.

SEIF, N., E. TAFAZZOLI., A.R. TALAII., V. ABOUTALEBI., A. ABDOSI. 2014. Evaluation of two grape cultivars (Vitis vinifera L.) against salinity stress and surveying the effect of methyl jasmonate and epibrassinolide on alleviation the salinity stress, 2014, International Journal of Biosciences, 5(7): 116-125.

SEKMEN, AH., R. OZGUR., B. UZILDAY., I. TURKAN. 2014. Reactive oxygen species scavenging capacities of cotton (Gossypium hirsutum) cultivars under combined drought and heat induced oxidative stress Environmental and Experimental Botany, 99: 141-149.
SHAHIN, M.F.M., M.I.F. FAWZI AND E.A. KANDIL. 2010. Influence of foliar application of some nutrient (Fertifol Misr) and gibberellin acid on fruit set, yield, fruit quality and leaf composition of "Anna" Apple trees grown in sandy soil. Journal of American Science. 6(12): 202-208.

SHAN, C., S.H. ZHANG., X. OU. 2018. The roles of $\mathrm{H} 2 \mathrm{~S}$ and $\mathrm{H}_{2} \mathrm{O}_{2}$ in regulating AsA-GSH cycle in the leaves of wheat seedlings under drought stress. Protoplasm, 255(4): 1257-1262.

SHARMA, P., A. BHUSHAN., R.S. DUBEY., AND M. PESSARAKLI. 2012. Reactive Oxygen Species, Oxidative Damage, and Anti oxidative Defense Mechanism in Plants under Stressful Conditions. Journal of Botany, 26.

SIDDIQUI, H., S. HAYAT., A. BAJGUZ. 2018. Regulation of photosynthesis by brassinosteroids in plants. Acta Physiologiae Plantarum, 40-59.

SUZUKI, N., SH. KOUSSEVITZKY., R. MITTLER., AND G. MILLER. 2012. ROS and redox signaling in the response of plants to abiotic stress. Plant, Cell and Environment, 35: 259-270.

VALENTOVIČ, P., M. LUXOVÁ., L. KOLAROVIČ., AND O. GAŠ́PARÍKOVÁ. 2006. Effect of osmotic stress on compatible solutes content, membrane stability and water relations in two maize cultivars. Plant Soil and Environment 52 (4): 186-191.

VARDHINI, B.V. 2013. Brassinosteroids role for amino acids, peptides and amines modulation in stressed plants are view, in Plant Adaptation to Environmental Change: Significance of Amino Acids and their Derivatives, eds N. A. Anjum, S.S. Gill, and R. Gill (Wallingford, CT: CAB International), 300-316.

XOCONOSTLE-CAZAREZ, B., F.A. RAMIREZORTEGA., L.F. ELENES., AND R. RUIZMEDRANO. 2012. Drought tolerance in crop plants. Am J Plant, 5(5): 241-256.

ZELINOVÁ, V.,I. MISTRÍK., J. PAVLOVKIN., AND L. TAMÁS. 2013. Glutathione peroxidase expression and activity in barley root tip after shortterm treatment with cadmium, hydrogen peroxide and t-butyl hydro peroxide. Protoplasm, 250(5): 1057-1065. 